\title{
Assessing the Impacts of Large-Scale Agro-Industrial Sugarcane Production on Biodiversity: A Case Study of Wonji Shoa Sugar Estate, Ethiopia
}

\author{
Sileshi Degefa * and Osamu Saito \\ United Nation University Institute for the Advanced Study of Sustainability, 5-53-70 Jingumae, \\ Shibuya, Tokyo 150-8925, Japan; saito@unu.edu \\ * Correspondence: geleto@student.unu.edu; Tel.: +81-080-21922190
}

Received: 19 October 2017; Accepted: 30 November 2017; Published: 4 December 2017

\begin{abstract}
Despite the intense debates on the land acquisition effects of large-scale Ethiopian sugarcane plantations and the consequences for food security, the impact on biodiversity has received less attention. We compared remnant patches in the sugarcane zone to the adjacent woodlands to determine the impacts of sugarcane on the diversity, composition, and structure of woody species. We recorded individual woody specimens with diameter at breast height $(\mathrm{DBH}) \geq 2.5 \mathrm{~cm}$ from 56 quadrats of $200 \mathrm{~m}^{2}$ at each site in a systematic, random, and gradient-oriented transect design. In addition, we employed a trait-based risk assessment framework to examine the threat posed by agro-industrial sugarcane production on mammals, birds, and rodents. A total of 56 woody species, 38 in the woodlands and 30 in the sugarcane zone, were identified. The proportion of non-native woody species was higher $(63 \%)$ in the sugarcane zone than in the adjacent woodlands $(1 \%)$. The rodents and mammals were more abundant in the woodlands than in the sugarcane zone. Although we did not investigate all of the bird and mammal species, our results identified six rodent species, five mammal species, and one bird species as susceptible to sugarcane agriculture activities. The results suggest that large-scale agro-industrial sugarcane production impacts species diversity, composition and abundance of species, and species' resource requirements.
\end{abstract}

Keywords: biodiversity; woody species; industrial crop; sugarcane; trait based; risk score

\section{Introduction}

Sub-Saharan Africa (SSA) is an important region for biodiversity conservation because it hosts nine of the 34 global biodiversity hotspots [1]. However, despite the significant desire for conservation, biodiversity is rapidly declining in this region. Agriculture is the primary driver of habitat loss and threatens biodiversity in all human-dominated landscapes [2], SSA [3], and Ethiopia [4,5]. Unfortunately, since the mid-2000s, SSA biodiversity has faced additional challenges due to large-scale industrial crop expansions [6-8]. Ethiopia has recently been targeted for large-scale industrial crop expansions $[9,10]$. Foreign and domestic actors acquired large tracts of land. As of 2013, of the 11,545,902 ha of potential land identified by the Ministry of Agriculture for investment, 2.11 million ha (11.5\% of the total land under cultivation) was allotted to large-scale agriculture, 303,500 ha of which was for sugarcane [11]. Moreover, in the second Growth and Transformation Plan period (2015-2020), 5 million ha was allocated to large-scale agriculture. Furthermore, allocation of land to sugarcane production has swiftly expanded in response to the government's green growth discourse, i.e., the government's plan to decouple the economic growth from carbon emission via adopting low carbon energy sources. Following the formulation of the 2007 Biofuel Development and Utilization Strategy, associated with the emerging green growth discourse, large tracts of land were designated for sugarcane. For example, 7895 ha were added to our study site, Wonji Shoa Sugar Estate (hereafter called "WSSE"), between 2007 and 2016 [12]. 
Climate change mitigation and energy security goals drive biofuel crop expansion globally [13]. In SSA, which includes Ethiopia, there are additional drivers of this expansion, such as foreign investment, export revenue, and economic development contributions $[7,8,14]$. One of the aims of sugar sector development in Ethiopia is to improve rural energy access, as the use of ethanol in rural communities reduces reliance on solid fuel for cooking and improves biodiversity conservation [15]. However, the existing large-scale ethanol distilleries in Ethiopia were designed for transport fuel and do not improve rural energy access. Therefore, there is a deep concern that large-scale sugarcane may accelerate biodiversity loss in the region.

The use and production of industrial crops for biofuel can affect biodiversity in several ways, including driving direct or indirect land-use changes. Direct land-use change occurs when industrial crops replace natural ecosystems [16]. For example, oil palm expansion caused $2.8 \%$ and $6.5 \%$ of the deforestation in Indonesia and Malaysia, respectively, while the soybean industry contributed to $5.9 \%$ of the deforestation in Mato Grosso, Brazil [17]. Converting biodiversity-rich habitats into monoculture crops, such as sugarcane, reduces species richness and abundance to a level where species can no longer play their original ecological roles. Indirect land-use change (ILUC) occurs when industrial crops displace and/or shift previously productive lands (e.g., agriculture or pasture) to other areas, which in turn can cause further biodiversity loss [18]. For example, sugarcane ethanol caused 0.23-0.38 ha of ILUC per 1000 L in Brazil [19]. However, Dale et al. [20] reported that careful planning can reduce biodiversity loss due to biofuel production.

Soil, water, and air pollution from the cultivation, transportation, harvest, and refining of sugarcane also contribute to biodiversity loss [21]. Agrochemical residues and effluents from industrial processes can lead to biotic contamination and habitat eutrophication [8], while repeated tillage and sustained irrigation can cause soil erosion and soil salinity, respectively. Furthermore, the conversion of natural ecosystems to sugarcane production may generate a greater amount of GHG emissions than the reductions gained from replacing fossil fuels with ethanol [22]. In addition, preharvest fires can directly affect small mammals and microbial communities [23].

Sugarcane agro-industrial production also consumes excessive amounts of water [24]. For example, the amount of water required to produce $1 \mathrm{~L}$ of sugarcane ethanol is $2450 \mathrm{~L}, 2995 \mathrm{~L}$, and $2775 \mathrm{~L}$ in Brazil, India, and the USA, respectively [25]. The large amount of water required to grow and process sugarcane competes with the downstream ecosystem water usage [26]. Unlike hydropower, which uses water directly in the stream, sugarcane irrigation and industrial processes involve the removal of water from natural water bodies [27].

According to the International Union for the Conservation of Nature, many biofuel crops are invasive [28] and pose great risks to biodiversity. Although sugarcane itself is not invasive, sugarcane management operations may facilitate the spread of invasive species [29]. For example, 116.4 ha of an irrigation canal were infested by water hyacinth (Eichhornia crassipes) at Wonji Sugar Estate, Ethiopia [30].

Regardless of the numerous ways that biofuels affect biodiversity, empirical studies are limited due to a lack of temporal baselines that capture the full suite of environmental impacts. Historical satellite image analysis is among the methods used to characterize the baseline conditions. However, this technique fails to detect species changes to the necessary level of detail. Therefore, the impacts of land-use change due to sugarcane and agro-industrial sugar production on biodiversity must be assessed by comparing taxonomic indicators (one species or if possible, many species) in the sugarcane zone forest patches with those existing in relatively untouched habitats. Moreover, it is necessary to understand the mechanisms through which sugarcane agro-industrial production affects different species' basic resource requirements. Despite the rapid expansion of the sugarcane plantation to the forest area in Ethiopia, there is a limited information on its species level biodiversity impacts.

The objectives of this study are to assess the woody species diversities of the sugarcane-zone forest patches and adjacent natural forests and to examine the impacts of sugarcane agro-industrial production on mammal, bird, and rodent resource needs. To accurately represent large-scale Ethiopian 
agriculture trends, the WSSE was selected as a study site due to its location in the Awash basin (Figure 1), an area of concentrated sugarcane projects [31].

\section{Materials and Methods}

\subsection{Study Area}

The WSSE is located in the East Shoa Zone of Oromia National Regional State at $8.38^{\circ} \mathrm{N} 39.30^{\circ}$ E, $107 \mathrm{~km}$ east of Addis Ababa (Figure 1). The WSSE lies between 1223 and $1553 \mathrm{~m}$ above sea level. Currently, the WSSE occupies 12,000 ha; the out-growers and the estate grow sugarcane on 7000 ha and 5000 ha, respectively. Approximately 9319 households (6184 male-headed and 3135 female-headed) participate in the out-grower scheme. Each household possesses between 0.2 and 6 ha of land [12] and the out-growers supply $60 \%$ of the total sugarcane crushed per year.

Currently, Awash River basin vegetation is changing dramatically due a high concentration of large-scale agriculture. The Wonji Shoa, Metehara, Kesem Kebena, and Tendaho sugar factories and the Amibera, Gewane, and Tendaho cotton farms are located in the basin.

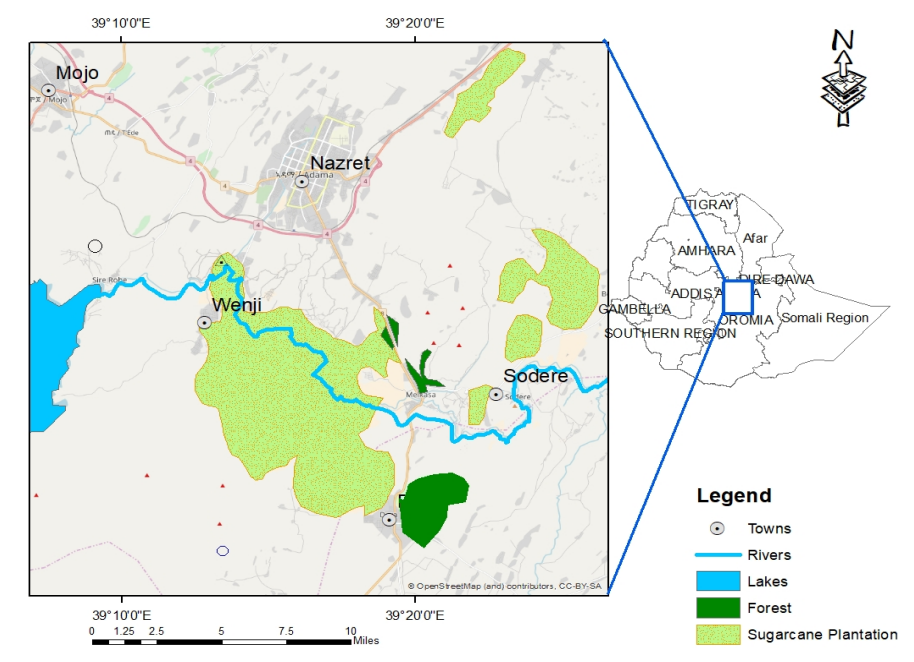

Figure 1. Map of the study area.

The area has a semi-arid climate (Figure 2) with a 70-mm ten-year mean monthly rainfall, $27^{\circ} \mathrm{C}$ mean monthly maximum temperature, and $12{ }^{\circ} \mathrm{C}$ mean monthly minimum temperature. The soils of the WSSE are predominantly Andosols, Fluvisols, Leptosols, and Phaeozemes, according to the FAO soil classification.

Ten-year mean monthly temperature and rainfall

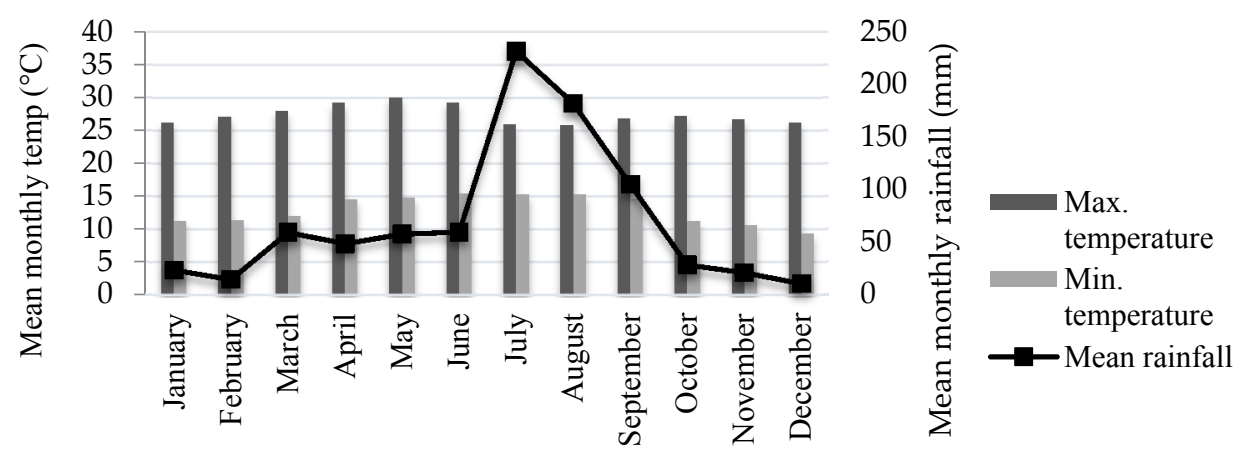

Figure 2. Ten-year (2007-2016) mean monthly temperature and rainfall. 


\subsection{Study Design and Data Collection}

First, we applied plant community sampling techniques [32] to compare the woody species compositions of the remnant sugarcane-zone patches to those of the adjacent woodlands. We computed the Shannon-Wiener Index (H), Simpson Index (1-D), Berger-Parker Index and Fisher's- $\alpha$ index, as well as Jaccard's and Sorenson's similarity indices. Second, we used previously collected data from the sugarcane zone and the adjacent woodlands and bushes to calculate a risk score for each rodent species using their feeding and nesting behavior [33]. As defined by previous authors, the risk of agricultural change $x$ to species $y$ is the degree of overlap between the environmental threats from the agricultural change and the resource requirements of a particular species [34,35]. The risk score was regressed against the species relative abundance. Third, we identified resource requirements for selected mammals and birds based on interviews and secondary sources. We selected species that are often used as taxonomic indicators in biodiversity assessments and also according to data availability. We calculated a risk score for each species by analyzing the overlap of the environmental threats from sugarcane and species-specific resource requirements. Then, we analyzed the relationship between the calculated risk scores and the qualitative population trend of each species.

\section{Woody Species Census Plots}

We conducted a floristic survey in the woodlands adjacent to the sugarcane zone to obtain baseline data on the presugarcane habitat. All of the woodlands were within $2 \mathrm{~km}$ of the sugarcane plantation. Semi-pastoral community occupied the land before the sugarcane where acacia woodlands are scattered and partly forested [31]. The WSSE annexed the plain area for the sugarcane expansion and the remaining land was gazetted as Regional Park (Dera Dilfaqar) in 1995. Dera Dilfaqar Regional Park has a total area of 1340.7 ha. The major soil types of the area are Andosols, Leptosols and Cambisols according to FAO soil classification. Its altitude ranges 1706-1835 m above sea level. In addition, we surveyed semi-natural remnant patches around sub-camps and rocky areas of the Wonji Shoa Sugar Estate. Field surveys were conducted in February, September, and October of 2016. We set up our sampling plots according to plant community sampling techniques [32]. We applied a gradient-oriented transect sampling technique in sloped areas because plant communities may vary along a slope. In flat areas, we employed a random-systematic sampling design and constructed $10 \mathrm{~m} \times 20 \mathrm{~m}$ quadrats separated by $60 \mathrm{~m}$ along a transect line. The subsequent transect lines were laid at each $5 \mathrm{~m}$ decrease in altitude in sloped areas and every $50 \mathrm{~m}$ in flat areas (Figure 3). Our survey focused on all living woody species (e.g., trees, shrubbery, and woody climbers) with diameters at breast height $(\mathrm{DBH}) \geq 2.5 \mathrm{~cm}$ and heights $\geq 0.5 \mathrm{~m}$. The tree height and DBH were measured with a hypsometer and a diameter tape, respectively. The branched trees were treated as a single unit with the average stem $\mathrm{DBH}$ used to represent the $\mathrm{DBH}$. Trees with abnormalities at $\mathrm{DBH}_{1.3 \mathrm{~m}}$ were measured either above or below the point at which they resumed a cylindrical form.

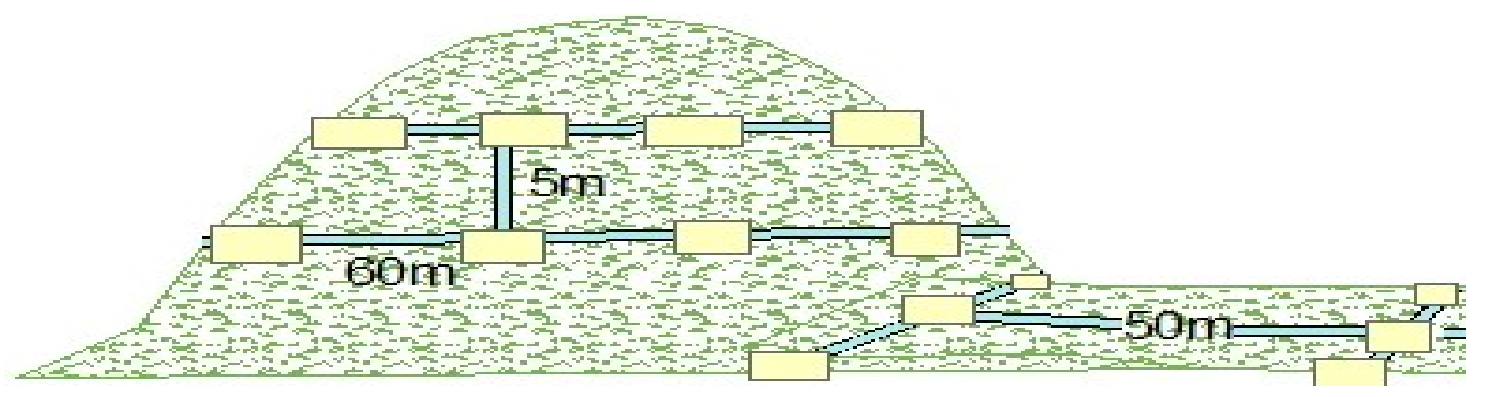

Figure 3. Woody species survey sampling plot. The number of samples $(\mathrm{N})$ at each location was 56; the quadrat area was $200 \mathrm{~m}^{2}$; the distance between quadrats was $60 \mathrm{~m}$; and transect lines were placed every $50 \mathrm{~m}$ on flat areas and at each $5 \mathrm{~m}$ decrease in altitude in sloped areas. 


\subsection{Risk Score Assessment Framework}

We administered a semi-structured questionnaire to 40 selected (36 elderly persons who were longtime residents of the area and had knowledge of the presugarcane condition, two experts from the Adama District Environment and Land Admiration Bureau, and two experts from the Dilfaqar Enclosure Area Management Office) individuals. As a result of limited population trend data, the informants provided qualitative population trend information (i.e., increasing, stable, or decreasing) for mammals and birds species that they were familiar with. The questionnaire also contained questions about foraging and nesting habitats, and we augmented these data with eco-requirement information from secondary sources. In addition, the informants listed the environmental threats from the sugarcane plantation and processing that they believed contributed to the decline and/or disappearance of species.

Using the overlaps of the six top environmental threats and species' eco-requirements, we calculated a risk score for each species. The risk score reflects the proportion of a species' resource requirements affected by environmental threats. Moreover, when the score is summed across all of the threats, we obtain the total risk score. We adopted the risk assessment framework technique, which has been applied to farmland birds in the UK [34,35]. This framework assumes that each threat source has an equal weight in its relationship with population growth and that the threats have additive effects [35]. The risk score varies with the degree of overlap between the environmental threats from the sugarcane and the degree of species reliance on a particular habitat for resources. Species that are found in one or two habitats/biotopes were assumed to have a major reliance $(R=1)$, those that occur in three or four habitats had a moderate reliance $(R=2)$, and those found in five or more biotopes were scored as having a minor reliance on the land occupied by sugarcane $(R=3)$. Information on the risk assessment framework for each species are included in Supplementary 1,2,3.

\section{(a) Rodent risk scores}

We relied on a secondary source that compared the species composition, abundance, and habitat association of small mammals (rodents and insectivores) in the WSSE with the adjacent woodland and bushes [33]. From rodent data in various habitats during both the wet and dry seasons, we identified the foraging and nesting habitat preferences for each species. An analysis of the stomach contents of each species was used to represent the food preferences of each species. We calculated the risk score for each rodent species by analyzing the environmental threats to the foraging, nesting, and feeding habitat preferences. We regressed the risk score against the species abundance to understand the relationship between these variables. The risk assessment framework was inspired by previous studies [34,35].

$$
R S=\frac{(D t+N t)}{R}
$$

where $R S$ is the risk score, $D t$ is the risk associated with food availability, $N t$ is the risk score associated with reduced breeding success, and $R$ is the reliance of a species on a given habitat. The species' reliance on a given habitat was determined by the trapping successes of that particular species in different habitats.

$$
D t=\frac{A}{(D * F)}+\frac{B}{F}
$$

where $A$ is the quantity of environmental threat and species' dietary component use overlap points and $B$ is the quantity of environmental threat and the species' foraging habitat use overlap points. $D$ and $F$ indicate the total number of dietary components and total number of foraging habitat components used by the species, respectively. The dietary components were determined by examining the stomach contents of each rodent. We did not consider unidentified components in the risk score calculation.

$$
N t=\frac{C 1}{N}+\frac{C 2}{N}
$$


where $C 1$ and $C 2$ indicate the numbers of overlap points of environmental threats from sugarcane and the species' usage of nesting habitat components that leads to conditions of reduced nesting in existing habitats and the loss of habitat, respectively. $N$ indicates the number of nesting habitat components used by the species. The detailed risk assessment is included in the Supplementary 1.

(b) Mammal and bird risk scores

Based on presence-absence information from the informants, we identified 26 mammal species in the sugarcane and adjacent woodland areas and selected 10 species that were frequently seen in the sugarcane zone. Similarly, we compiled a list of identified bird species in the area using secondary sources and selected three bird species that were frequently observed in the sugarcane zone. We constructed species resource requirements based on information from our informants and from the literature. Despite broad species resource needs, we focused on the foraging and nesting/roosting requirements [35]. The changes due to sugarcane can be positive or negative; however, only the detrimental changes were included in the risk assessment framework. As there were no monitoring data, we relied on qualitative population trends provided by informants. Thus, the population trends only reflected the local area. The informants categorized the population trends of each species as decreasing, stable, or increasing based on their day-to-day observations over the last two decades. The risk assessment frameworks are included in Supplementaries 2 and 3. And the risk scores were calculated using Equations (1)-(3).

\subsection{Floristic Data Analysis}

Sample specimens were taken to the national herbarium at Addis Ababa University for species identification. We coded the species in an MS-Excel spreadsheet and used PAST Software to compute the $H, 1-\mathrm{D}$, species evenness (e^H/S), equitability (J), and Fisher's- $\alpha$ and Whittaker's Beta diversity indices. The $H$ incorporates both the species abundance and the evenness. The Simpson Index is the probability that two randomly-selected individuals from a sample will belong to different species. The Berger-Parker Index is a measure of the numerical importance of the most abundant species. Its reciprocal is often used and an increase in the index value corresponds with an increase in diversity and a reduction in dominance. Whittaker's Beta diversity index measures the species turnover. The species evenness is the proportion of individuals among the species. Equitability measures the evenness of individuals among the species present. We assessed the floristic similarity between the groups using Jaccard's and Sorenson's similarity indices. The importance value index (IVI), a function of the relative density, relative frequency, and relative dominance, was computed following Curtis and McIntosh [36].

\section{Results}

\subsection{Floristic Composition and Diversity}

We recorded a total of 56 different species; 38 species from 20 families were identified in the woodlands and 30 species from 14 families were recorded in the sugarcane zone. The sample rarefaction curve (Figure 4) shows that additional sampling efforts would add few additional species. Despite no significant differences in the species evenness at $\alpha=0.05$, all of the diversity indices showed significant differences in species diversity and dominance between the natural ecosystem and the sugarcane zone (Table 1). The adjacent woodlands contained more species and families than the remnant patches in the sugarcane zone. Fabaceae was the most common family and constituted $67.6 \%$ and $38.8 \%$ of the families in the natural ecosystem and sugarcane zone, respectively. The natural ecosystem rarefaction curve also indicated greater diversity because it lies outside the upper limit of the sugarcane zone curve. Whittaker's beta diversity was higher in the sugarcane zone $(\beta=7.68)$ than in the natural ecosystem $(\beta=6)$. The two sites showed low biotic similarity with only 12 species in common and with Jaccard's and Sorensen's similarity indices of 0.38 and 0.35 , respectively (Table 1 ). The proportion 
of non-native woody species was high (63\%) in the sugarcane zone than in the adjacent woodlands $(1 \%)$.

Table 1. Calculated species richness, diversity, evenness, and similarity indices for the sugarcane zone and the adjacent natural ecosystem. Significance level of $p \leq 0.05$.

\begin{tabular}{ccccc}
\hline Diversity Index & Sugarcane Zone & Natural Ecosystem & $\boldsymbol{t}$-Value & $\boldsymbol{p}$ Value $(\boldsymbol{p} \leq \mathbf{0 . 0 5})$ \\
\hline Species richness & 30 & 38 & 5.03 & 0.0001 \\
Dominance (D) & $0.54 \pm 0.24$ & $0.36 \pm 0.17$ & 5.03 & 0.0001 \\
Simpson (1-D) & $0.45 \pm 0.24$ & $0.63 \pm 0.17$ & 0.0000 \\
Shannon (H) & $0.83 \pm 0.50$ & $1.30 \pm 0.43$ & 5.67 & 0.2120 \\
Evenness (e`H/S) & $0.77 \pm 0.17$ & $0.72 \pm 0.16$ & 1.25 & 0.0900 \\
Equitability (J) & $0.73 \pm 0.21$ & $0.77 \pm 0.17$ & 1.98 & 0.0014 \\
Fisher alpha & $1.42 \pm 0.92$ & $2.00 \pm 1.10$ & -3.54 & 0.0000 \\
Berger-Parker & $0.64 \pm 0.22$ & $0.48 \pm 0.19$ & 1.96 & \\
Whittaker's Beta diversity & 7.68 & 6.60 & \\
\hline \multicolumn{5}{c}{0.38} \\
Jaccard's Index & \multicolumn{5}{c}{0.35} \\
Sorensen's Index
\end{tabular}

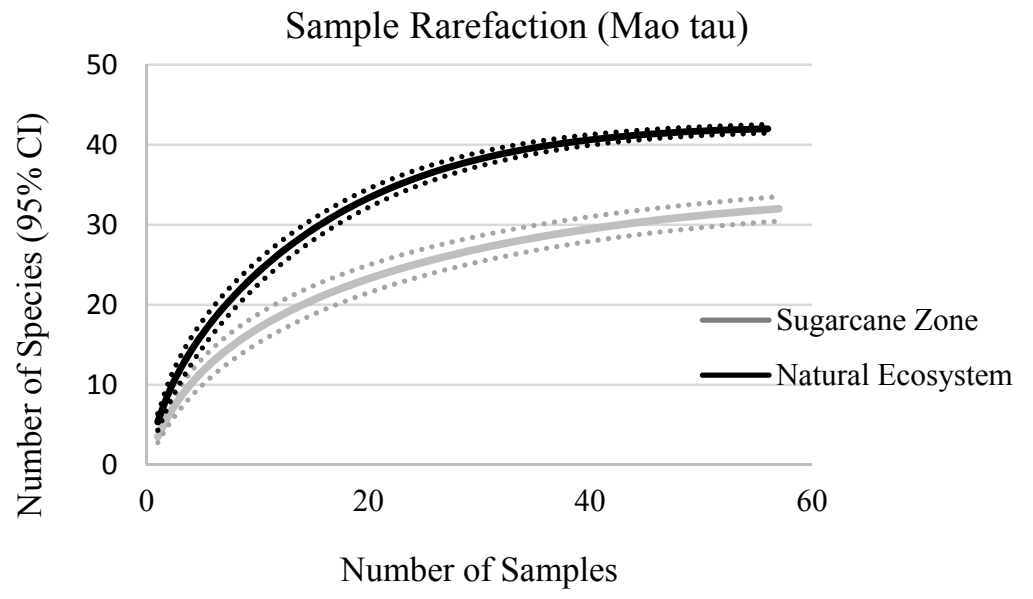

Figure 4. Species accumulation (rarefaction) curves (solid lines) and 95\% confidence intervals (dashed lines).

\subsubsection{Important Value Index}

The woodlands harbored native species such as Acacia nilotica, Acacia etbaica, Acacia tortilis, and Balanites aegyptiaca. Conversely, non-native species, such as Casuarina equisetifolia, Eucalyptus globulus, and Sesbania grandiflora, dominated patches within the sugarcane zone. Of the ten species in the natural ecosystem with the highest IVI values, only Eucalyptus globulus was exotic. Conversely, all of the species with the highest IVI values in the sugarcane zone were exotic except for Ficus sycomorus, Acacia seyal Del, and Ehretia cymosa (Table 2). 
Table 2. The important value index (IVI) of natural ecosystem and sugarcane-zone woody species. The IVI is the sum of the relative frequency (RF), relative density (RD), and relative basal area (RBA). Each relative measure value ranges from $0 \%$ to $100 \%$, and the IVI value ranges from $0 \%$ to $300 \%$. * denotes a non-native species, while ${ }^{* *}$ denotes a fruit tree.

\begin{tabular}{|c|c|c|c|c|c|c|c|c|c|}
\hline $\begin{array}{l}\text { Natural Ecosystem } \\
\text { Species }\end{array}$ & RF \% & RD \% & RBA \% & IVI & $\begin{array}{c}\text { Sugarcane-Zone } \\
\text { Species }\end{array}$ & RF \% & RD \% & RBA \% & IVI \\
\hline Acacia nilotica & 18.52 & 27.64 & 18.89 & 65.05 & Casuarina equisetifolia * & 15.92 & 14.66 & 17.18 & 47.76 \\
\hline Acacia etbaica & 11.63 & 27.31 & 13.41 & 52.35 & Eucalyptus globulus * & 9.95 & 20.11 & 15.53 & 45.59 \\
\hline Acacia tortilis & 6.89 & 4.85 & 33.79 & 45.53 & Sesbania grandiflora * & 11.94 & 21.79 & 8.45 & 42.18 \\
\hline Balanites aegyptiaca & 12.92 & 7.53 & 6.95 & 27.40 & Ficus sycomorus & 1.49 & 0.49 & 36.80 & 38.79 \\
\hline Acacia Senegal & 10.34 & 10.15 & 6.14 & 26.63 & Grevilea robusta * & 7.46 & 5.59 & 4.67 & 17.72 \\
\hline Dichrostachys cineera & 9.91 & 8.45 & 2.94 & 21.30 & Jacaranda mimesifolia * & 7.46 & 8.38 & 0.50 & 16.34 \\
\hline Eucalyptus globulus * & 1.29 & 2.55 & 8.27 & 12.12 & Acacia seyal & 5.97 & 6.22 & 0.64 & 12.82 \\
\hline Acacia oerfota & 2.58 & 1.96 & 0.60 & 5.14 & Delonix rigia * & 2.98 & 2.79 & 3.66 & 9.43 \\
\hline Acacia mellifera & 2.58 & 0.85 & 0.52 & 3.96 & Ehretia cymosa & 4.97 & 2.72 & 0.20 & 7.90 \\
\hline Maerua angolensis & 0.86 & 0.85 & 1.86 & 3.57 & Spathodea nilotica * & 2.49 & 2.37 & 2.99 & 7.85 \\
\hline Rhus natalensis & 2.15 & 1.18 & 0.08 & 3.41 & Millettia ferruginea & 3.98 & 2.30 & 0.28 & 6.56 \\
\hline Acokanthera schimperi & 1.72 & 0.85 & 0.54 & 3.12 & Acacia senegal & 2.49 & 0.77 & 2.43 & 5.69 \\
\hline Acacia seyal & 0.86 & 1.77 & 0.44 & 3.07 & Cupress lustanica* & 1.99 & 1.82 & 1.26 & 5.07 \\
\hline Calpurnia aurea & 2.15 & 0.79 & 0.12 & 3.06 & Cordia africana & 2.98 & 1.89 & 0.04 & 4.91 \\
\hline Ehertia cymosa & 2.15 & 0.72 & 0.16 & 3.04 & Albizia gummifera & 2.98 & 1.19 & 0.44 & 4.61 \\
\hline Ziziphus mauritiana & 0.86 & 1.18 & 0.92 & 2.96 & Schinus molle* & 1.49 & 0.77 & 0.64 & 2.90 \\
\hline Pappea capensis & 0.86 & 0.52 & 1.17 & 2.55 & Mangofera indica ** & 0.99 & 0.63 & 1.16 & 2.78 \\
\hline Terminalia brownie & 0.86 & 0.72 & 0.74 & 2.32 & Carica papaya $* *$ & 0.50 & 1.89 & 0.20 & 2.58 \\
\hline Commiphora rostrata & 0.86 & 1.18 & 0.21 & 2.25 & Juniperus procera & 0.99 & 0.49 & 1.08 & 2.56 \\
\hline Cadaba farinose & 1.29 & 0.85 & 0.10 & 2.24 & Balanites aegyptiaca & 1.49 & 0.56 & 0.40 & 2.45 \\
\hline Cordia ovalis & 0.86 & 0.79 & 0.58 & 2.23 & Podocarpus falcatus & 1.49 & 0.42 & 0.54 & 2.45 \\
\hline Croton dichogamous & 1.29 & 0.79 & 0.07 & 2.15 & Cajanus cajan & 1.49 & 0.70 & 0.05 & 2.24 \\
\hline Capparis fascicularis & 1.72 & 0.33 & 0.05 & 2.10 & Croton macrostachyus & 0.99 & 0.63 & 0.04 & 1.66 \\
\hline Grewia tenax & 1.29 & 0.72 & 0.04 & 2.05 & Phonix reclanata & 0.99 & 0.14 & 0.33 & 1.46 \\
\hline Cordia africana & 0.86 & 1.11 & 0.06 & 2.04 & Acacia nilotica & 0.99 & 0.14 & 0.32 & 1.46 \\
\hline Syzygium guineensis & 0.86 & 0.72 & 0.44 & 2.02 & Dichrostachys cineera & 0.99 & 0.14 & 0.07 & 1.20 \\
\hline Dodonea angustifolia & 0.86 & 0.92 & 0.07 & 1.85 & Capparis tomentosa & 0.99 & 0.14 & 0.02 & 1.15 \\
\hline Croton macrostachyus & 0.86 & 0.79 & 0.16 & 1.81 & Psidium guajava & 0.50 & 0.14 & 0.03 & 0.67 \\
\hline Myrsine africana & 0.86 & 0.85 & 0.04 & 1.75 & Acacia abyssinica & 0.50 & 0.07 & 0.04 & 0.61 \\
\hline Fleuggea virosa & 0.86 & 0.79 & 0.05 & 1.69 & Caesalipinia dectaptela & 0.50 & 0.07 & 0.02 & 0.59 \\
\hline Maytenus senegalensis & 0.86 & 0.72 & 0.08 & 1.66 & & & & & \\
\hline Premna resinosa & 0.86 & 0.72 & 0.07 & 1.66 & & & & & \\
\hline Capparis tomentosa & 0.86 & 0.65 & 0.12 & 1.63 & & & & & \\
\hline Caesalipinia dectaptela & 0.86 & 0.65 & 0.03 & 1.55 & & & & & \\
\hline Asparagus africanus & 0.86 & 0.59 & 0.00 & 1.45 & & & & & \\
\hline Ficus sycomorus & 0.86 & 0.33 & 0.23 & 1.42 & & & & & \\
\hline Grewia villosa & 0.86 & 0.46 & 0.02 & 1.34 & & & & & \\
\hline Grewia bicolor & 0.86 & 0.39 & 0.02 & 1.28 & & & & & \\
\hline
\end{tabular}

\subsubsection{Vegetation Structure}

The distribution of woodland DHB classes shows an inverted "J" shape (Figure 5a), where the first, second, and third classes represent $21.8 \%, 42.2 \%$, and $23.7 \%$ of the total population, respectively. Trees with DBH values of $\leq 15 \mathrm{~cm}$ constitute $87.7 \%$ of all of the recorded individuals. Acacia tortilis and Eucalyptus globulus had DBH values of $\geq 50 \mathrm{~cm}$. The proportion of individuals with DBH values of $\leq 15 \mathrm{~cm}$ in the sugarcane zone was $65 \%$. Similarly, the proportion of individuals in short-height classes was high in the woodlands (Figure $5 b$ ). The DHB and height class distributions were statistically different between the natural ecosystems and sugarcane zone (i.e., $\chi^{2}=454.76, d f=8, p<0.05$ and $\chi^{2}=572.05, d f=6, p<0.00001$, respectively). 
a) $\mathrm{DBH}$ classes $(\mathrm{cm})$

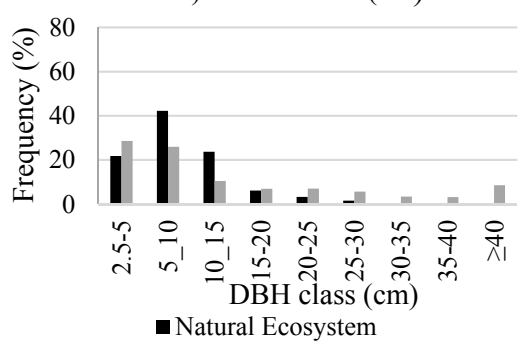

b) Tree height classes $(\mathrm{m})$

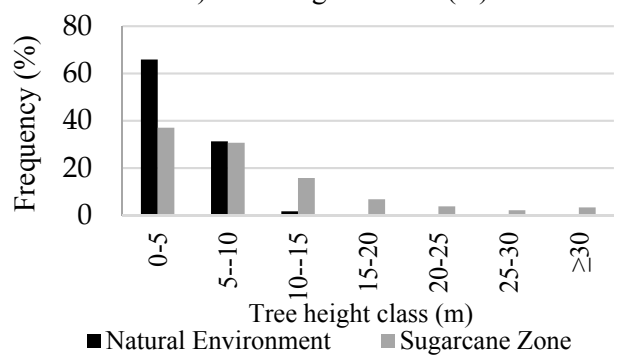

Figure 5. Frequency distributions of: (a) the DBH classes; and (b) the woody species height classes in the sugarcane-zone forest patches and in the adjacent natural ecosystem.

\subsection{Rodent Abundance and Risk Scores}

The results showed similar species richness for different sugarcane growth stages (immature, young, and mature) and in the adjacent woodlands and bushes. However, variations in the species abundance were statistically significant. Rodents were significantly more abundant in the adjacent woodlands and bushes than in the immature $\left(\chi^{2}=17.9, d f=9, p<0.05\right)$, young $\left(\chi^{2}=22.8, d f=9\right.$, $p<0.05)$, and mature $\left(\chi^{2}=39.34, d f=9, p<0.001\right)$ sugarcane plantations. The abundances of rodents were not significantly different between the dry and wet seasons in the sugarcane zone, but the difference between the dry and wet seasons was statistically significant in the adjacent natural ecosystem $\left(\chi^{2}=24.84, d f=9, p<0.05\right)$. The number of individuals trapped during the wet season was higher than that trapped during the dry season (A1). The risk score of the species ranged from 1.2 to 3.4 (Table 3). The mean risk score of rodent species with an equal to or greater abundance than the adjacent bushland was $1.78 \pm 0.19$. Six rodent species had risk scores of greater than $1.78 \pm 0.19$. In addition, the risk score was negatively correlated with the species abundance $(r=-0.75, p<0.05)$ (Figure 6). A multiple linear regression was used to predict the risk score using environmental threats from sugarcane as predictors. A significant regression equation was identified $(F(4,5)=119.22, p<0.000)$, with an $R^{2}$ of 0.989 . Fires, agrochemicals, and effluents were significant risk score predictors.

Table 3. Risk score and rodent abundance.

\begin{tabular}{ccc}
\hline Species Name & Risk Score & Abundance (\%) \\
\hline Mastomys natalensis & 1.21 & 27.33 \\
Arvicanthis dembeensis & 1.31 & 16.00 \\
Arvicanthis niloticus & 2.28 & 4.40 \\
Stenocephalemys albipes & 1.50 & 14.53 \\
Pelomys harringtoni & 2.39 & 8.62 \\
Mus mahomet Rhoads & 2.33 & 7.90 \\
Mus musculus Linnaeus & 1.84 & 5.42 \\
Rattus rattus Linnaeus & 3.44 & 3.70 \\
Crocidura flavescens & 2.34 & 6.40 \\
Crocidura fumosa & 2.04 & 5.70 \\
\hline
\end{tabular}

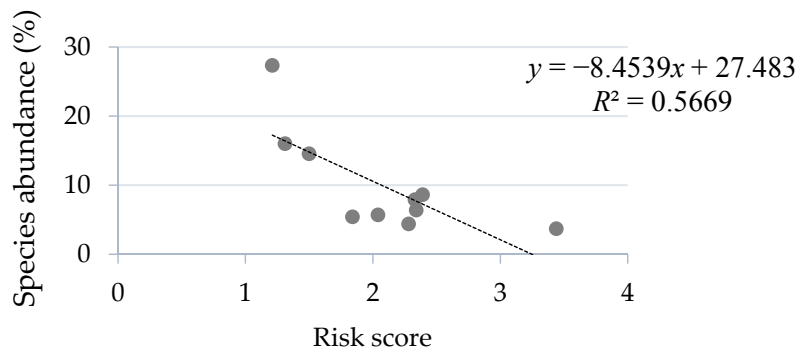

Figure 6. Species abundance versus rodent risk score. 


\subsection{Mammal and Bird Risk Scores}

The risk score mean \pm 1 SE for mammals and birds was $2.44 \pm 0.29$, while the risk score of the stable population was $1.67 \pm 0.49$. Species with a risk score greater than the point at which the taxa maintains a stable population are considered vulnerable [35]. Thus, five out of the 10 mammal species and one out of the three bird species were deemed susceptible to agro-industrial production of sugarcane. The susceptible species are both from inside and outside of the sugarcane zone. The risk score and qualitative population trend showed an inverse relationship (Figure 7a): decreasing and stable populations had higher risk scores than increasing populations. Human disturbance, fire, and effluent were important risk score predictors (Figure $7 \mathrm{~b}$ ).
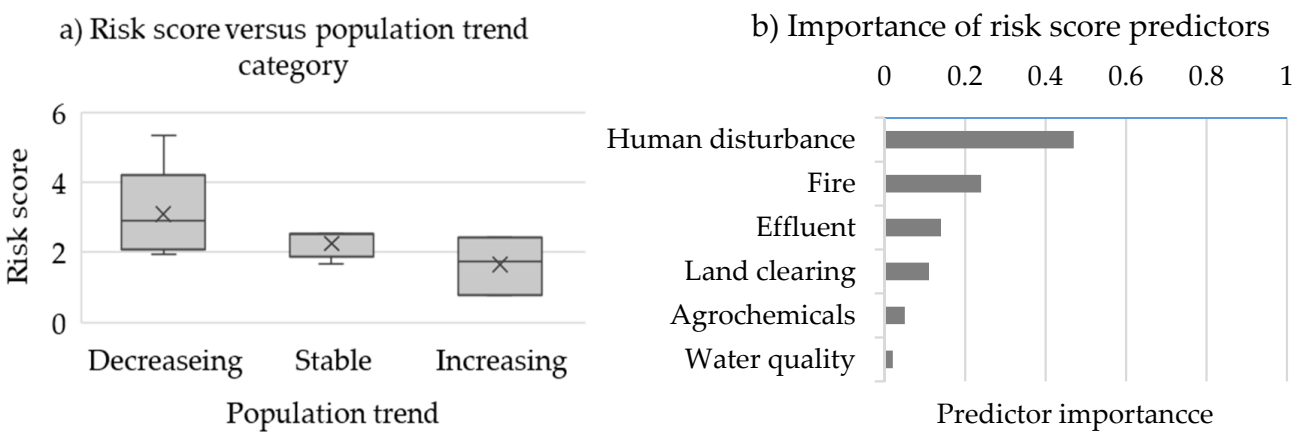

Figure 7. (a) Relationship between the risk score and the mammal and bird population trends; and $(\mathbf{b})$ the importance of the risk score predictors $(0.0=$ less important and $1.0=$ highly important).

The informants stated that before the steep decline in bird and mammal populations associated with the expansion of sugarcane, this area was home to more than 50 wild mammals. Whatever human disturbance may be, the absence of corridors to the water source (Awash River) seems to have been a lot worse. Approximately 26 mammals, including the greater kudu (Tragelaphus strepsiceros) and the lesser kudu (Tragelaphus imberbis), and 38 bird species still live in the adjacent Arsi Mountain National Park Dhera-Dilfaqar block (A2 and A3). The drinking water sources for these wild mammals are manmade concrete drinking troughs filled periodically by water trucks (Figure 8). There are six manmade concrete drinking troughs in the Dhera-Dilfaqar block (0535852 N, 0921388 E; 0535954 N, 0921492 E; 0533575 N, 0921573 E; 0536129 N, 0921843 E; 0536867 N, 0921110 E; and 0536925 N, 0922183 E). Moreover, the movement of mammals to the sugarcane zone in search of water and fresh grass exposes them to hunting risk.

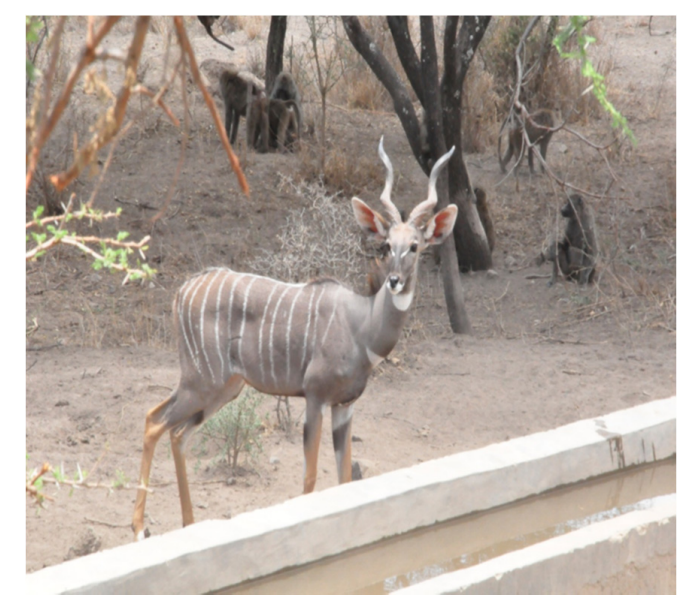

Figure 8. A greater kudu (Tragelaphus strepsiceros) drinking water from a manmade trough in the Dera-Dilfakar enclosure area (Source: unpublished report from Dera-Dilfakar Head Quarter). 


\section{Discussion}

\subsection{Floristic Composition, Richness, and Diversity}

Woodland diversity was within the range reported for the Awash National Park [37]. However, the lower diversity in the remnant patches within the sugarcane zone may be due to excessive anthropogenic disturbances associated with the sugarcane plantation. The absence of commercially important native species (except Ficus sycomorus) in the high DBH classes could be attributed to the severe human disturbances. These findings agree with a previous study that found a smaller number of economically significant trees in a severely disturbed, dry afro-montane forest in Ethiopia [38]. During sugarcane expansion, the original tree species were bulldozed to facilitate mechanization. The removal of mature trees, which serve as seed sources, may explain the extinction of the original species. Previous work has also shown that clearing of mature trees (seed sources) affects regeneration [39]. The clearing of original vegetation for labor camp construction and firewood harvesting during the expansion of the sugarcane plantation may have accelerated the vegetation composition change. A study in the Awash valley attributed the over-extraction of trees to commercial farms [10], and this process may have been quickened by a private/community to large sugar corporation ownership change. Furthermore, the change in farmers' livelihoods from small land-holders to wage earners may have triggered mass involvement in the charcoal production and firewood trades. Farmers who previously earned a living from mixed farming on $0.5-3.0$ ha per household are dependent on a monthly allowance of 13.6 USD per ha they receive until the first harvest [10]. Thus, impoverished households and their unemployed members engage in charcoal production to supplement incomes. In addition, a decline in pollinating agent dispersal and the gradual development of salinity likely contributed to low regeneration rates. A combination of factors altered the woody species composition in the sugarcane zone, as a greater number of constraints from human disturbances results in larger impacts on diversity and composition [40].

The Sorensen's and Jaccard's similarity coefficients were 0.35 and 0.38 , respectively. The low floristic dissimilarity may be due to a varying degree of exposure to human disturbances. In addition, high $\beta$-diversities ( ${ }^{\beta} \mathrm{w}>5$ ) imply a low similarity and high species turnover, whereas low $\beta$-diversities $\left({ }^{\beta} \mathrm{W}<1\right)$ imply a high similarity [41]. The high $\beta$-diversity in the sugarcane zone may be the result of human disturbances, which create conducive environments for new species. These disturbances can reduce the populations of original species and create "vacant niches" for new species to invade [42]. Conversely, dispersal limitations result in higher Whittaker's $\beta$-diversity. Due to the hostile environment of the sugarcane area for dispersal agents, such as mammals and birds, long distance dispersal is minimal, creating localized patches of habitat. Because, dispersal agents can determine the restoration success of habitats [43].

The high IVI of non-native tree species may be due to the selective logging of native species, human importation of non-native species, and the company's preference for exotic trees in landscaping and horticultural purposes. Approximately $50 \%$ of the species in the sugarcane zone had IVI values of less than 5 , indicating species rarity. The low IVI values help determine the conservation priorities of species [44].

The inverted "J" shape of the woodland diameter class distribution indicated satisfactory regeneration. Most of the natural ecosystem samples were taken from strictly protected areas. The strict protection from grazing and human disturbances is likely the reason for the satisfactory regeneration. This result was congruent with a study conducted in the same area [45], which found a high juvenile ratio in the protected areas close to homesteads. The low ratio of individuals in high DBH classes $(>30 \mathrm{~cm})$ may be due to the nature of the individual species. Human disturbances in the sugarcane zone reduced regeneration success, which determined the vegetation structure [46]. In addition, the removal of mature individuals, which serve as seed sources, may have caused a low seedling population in the sugarcane zone [47]. Moreover, co-planted exotic species in the sugarcane zone, such as Casuarina equisetifolia, Eucalyptus globulus, and Sesbania grandiflora, may have inhibited undergrowth 
species. A previous study reported that upper story species inhibited understory species regeneration in the Ethiopian afro-montane rainforest [46]. The high number of individuals in the sugarcane zone with $\geq 40$-cm DBH values is due to remnant indigenous trees, such as Ficus sycomorus, Juniperus procera, and Podocarpus falcatus, around sub-camps.

\subsection{Risk Score Assessment}

The low abundance of rodents in the sugarcane zone was perhaps due to a high mortality rate associated with preharvest fire and the deleterious side effects of agrochemicals. Gheler-Costa et al. [27] reported that rodents were more abundant in a sugarcane field where preharvest fires were halted for ten years than in a field with regular fires in São Paulo State, Brazil. Previous studies at Wonji Shoa showed a declining rodent species population [48], which may be due to preharvest fires during the dry season (October to May). In addition, pesticides sprayed in the area may have detrimental side effects on non-target rodents. However, pesticide is a common crop pest management technique, and only select species, such as M. natalensis, Rattus spp., and Arvicanthis spp., were reported as major pests. Moreover, the prominent sugarcane pest Rattus spp. was the least trapped in the study area [49]. The direct ingestion of ingredients or contaminated food items may lead to mortality of non-target birds, rodents, pollinator insects, and microbial communities. Secondary poisoning also occurs if birds and rodents feed on poisoned organisms, such as arthropods. Furthermore, fire and pesticide can eliminate other organisms in the sugarcane plantations, reducing the amount of forage for birds and rodents. For example, studies in other countries have shown the negative impacts of agro-industrial management associated with sugarcane production on microbial communities [50], bacterial communities [51], arthropods [52], and spider populations [53]. M. natalensis and Arvicanthis spp. showed low risk scores because these species are pests and depend less on the seed and animal matter that is adversely affected by fire and pesticides.

The decline of large mammals can be attributed to the loss of habitat area. The small remaining patches in the sugarcane zone cannot sustain viable populations of large mammals, despite sustaining rodent populations. As the study site has a semi-arid climate and experiences regular droughts, water is crucial for the survival of the wild mammals. The water scarcity in the area and the blockage of corridors to water sources and dry-season riverside grazing areas may contribute to declining wild mammal populations. This acute water scarcity in the Awash basin was detailed in a previous study [54]. The sugarcane expansion reduced the total amount of grazing area, which increased mammal crop raids and human-wildlife conflicts. In addition, workforce and machinery movements with preharvest fires may have scared mammals and caused them to abandon the area. However, well-adapted species to disturbances had low risk scores and stable or slightly increasing populations. The risk score for mammals was within the range reported in UK farmland [35]. Species with narrow resource needs, such as Hippopotamus amphibious, had high risk scores. The substantial decrease in the Awash River water level due to irrigation may have triggered the evacuation of hippopotamus. Mammals that lived in the area before the sugarcane plantation were rarely observed in the remnant sugarcane-zone patches, which agrees with previous findings from São Paulo State, Brazil [55].

\section{Conclusions}

This study demonstrated significant differences in the vegetation compositions and forest patch diversities of the sugarcane zone and adjacent natural forests. Native woody species were dwindling in the sugarcane zone and further sugarcane expansion is likely detrimental to the biodiversity. A close examination of an area recently converted to a sugarcane plantation revealed that the vegetation change was mainly due to human disturbances, such as land clearing during sugarcane expansion, over-extraction associated with ownership changes, and the preference of the corporation for exotic species. The current level of disturbance hinders the restoration of woody species in the sugarcane zone. Therefore, the WSSE and the Ethiopian Sugar Corporation should work with other stakeholders, such as local park managers, to protect and restore the original vegetation in the adjacent forests. 
In addition, it is important that the WSSE selects a targeted agrochemical pesticide, rather than a broad-spectrum product. A shift from a preharvest burn to a no-burn sugarcane management scheme may also help restore biodiversity in the area. Furthermore, rodents and mammals were more abundant in the adjacent land than in the sugarcane zone, and the risk score analysis indicated that six rodent species, five mammal species, and one bird species were susceptible to agro-industrial activities related to sugarcane. However, the lack of population growth rate data did not allow the validation of the risk assessment framework findings. Increased monitoring and collection of population growth rate data, presugarcane land-use histories, and agricultural management practices will greatly aid the effort to understand the impacts of sugarcane plantations on biodiversity.

Supplementary Materials: The following are available online at www.mdpi.com/2077-0472/7/12/99/s1, Supplementary 1: Detailed Description of Rodent Risk Assessment, Supplementary 2: Detailed Description of Mammal Risk Assessment, Supplementary 3: Detailed Description of Bird Risk Assessment.

Acknowledgments: This study was conducted as a part of the Food Security Impacts of Industrial Crop Expansion in Sub-Sahara Africa (FICESSA) project funded by Japan Science and Technology Agency. We are also grateful to Ethiopian Sugar Corporation Research Directorate and Dilfaqar Regional Park Management for their support during data collection.

Author Contributions: Both authors were involved in designing the study, analyzing the data, interpreting the result and writing the manuscript.

Conflicts of Interest: The authors declare no conflict of interest.

\section{References}

1. Stuart, S.N.; Adams, R.J. Biodiversity in Sub-Saharan Africa and Its Islands: Conservation, Management, and Sustainable Use; No. 6; Occasional Papers of the IUCN Species Survival Commission: Gland, Switzerland, 1990.

2. Board, M.E. Ecosystems and Human Well-Being, Biodiversity Synthesis: A Report of the Millennium Ecosystem Assessment; World Resources Institute: Washington, DC, USA, 2005.

3. DeGeorges, P.A.; Reilly, B.K. The realities of community based natural resource management and biodiversity conservation in Sub-Saharan Africa. Sustainability 2009, 1, 734-788. [CrossRef]

4. Darbyshire, I.; Lamb, H.; Umer, M. Forest clearance and regrowth in northern Ethiopia during the last 3000 years. Holocene 2003, 13, 537-546. [CrossRef]

5. Pistorius, T.; Carodenuto, S.; Wathum, G. Implementing Forest Landscape Restoration in Ethiopia. Forests 2017, 8, 61. [CrossRef]

6. Webb, A.; Coates, D. Biofuels and Biodiversity; Technical Series (No. 65); Secretariat of the Convention on Biological Diversity: Montreal, QC, Canada, 2012.

7. Schoneveld, G.C. The Challenge of Governing Africa's New Agricultural Investment Landscapes: An Analysis of Policy Arrangements and Sustainability Outcomes in Ethiopia and Nigeria. Forests 2014, 6, 88-115. [CrossRef]

8. Hess, T.M.; Sumberg, J.; Biggs, T.; Georgescu, M.; Haro-Monteagudo, D.; Jewitt, G.; Ozdogan, M.; Marshall, M.; Thenkabail, P.; Daccache, A.; et al. A sweet deal? Sugarcane, water and agricultural transformation in Sub-Saharan Africa. Glob. Environ. Chang. 2016, 39, 181-194. [CrossRef]

9. Moreda, T. Listening to their silence? The political reaction of affected communities to large-scale land acquisitions: Insights from Ethiopia. J. Peasant Stud. 2015, 42, 517-539. [CrossRef]

10. Lavers, T. Patterns of agrarian transformation in Ethiopia: State-mediated commercialisation and the 'land grab'. J. Peasant Stud. 2012, 39, 795-822. [CrossRef]

11. Teklemariam, D.; Azadi, H.; Nyssen, J.; Haile, M.; Witlox, F. How Sustainable Is Transnational Farmland Acquisition in Ethiopia? Lessons Learned from the Benishangul-Gumuz Region. Sustainability 2016, 8, 213. [CrossRef]

12. Wendimu, M.A.; Henningsen, A.; Gibbon, P. Sugarcane Out-growers in Ethiopia: "Forced" to Remain Poor? World Dev. 2016, 83, 84-97. [CrossRef]

13. Hertel, T.W.; Tyner, W.E.; Birur, D.K. The global impacts of biofuel mandates. Energy J. 2010, 75-100. [CrossRef] 
14. Lynd, L.R.; Sow, M.; Chimphango, A.F.; Cortez, L.A.; Cruz, C.H.B.; Elmissiry, M.; Laser, M.; Mayaki, I.A.; Moraes, M.A.; Nogueira, L.A.; et al. Bioenergy and African transformation. Biotechnol. Biofuels 2015, 8, 18. [CrossRef] [PubMed]

15. Muniz Kubota, A.; Dal Belo Leite, J.G.; Watanabe, M.; Cavalett, O.; Leal, M.R.; Cortez, L. The Role of Small-Scale Biofuel Production in Brazil: Lessons for Developing Countries. Agriculture 2017, 7, 61. [CrossRef]

16. Fitzherbert, E.B.; Struebig, M.J.; Morel, A.; Danielsen, F.; Brühl, C.A.; Donald, P.F.; Phalan, B. How will oil palm expansion affect biodiversity? Trends Ecol. Evol. 2008, 23, 538-545. [CrossRef] [PubMed]

17. Gao, Y.; Skutsch, M.; Masera, O.; Pacheco, P. A Global Analysis of Deforestation Due to Biofuel Development; CIFOR: Bogor, Indonesia, 2011.

18. Lapola, D.M.; Schaldach, R.; Alcamo, J.; Bondeau, A.; Koch, J.; Koelking, C.; Priess, J.A. Indirect land-use changes can overcome carbon savings from biofuels in Brazil. Proc. Natl. Acad. Sci. USA 2010, 107, 3388-3393. [CrossRef] [PubMed]

19. Nassar, A.M.; Moreira, M. Evidences on Sugarcane Expansion and Agricultural Land Use Changes in Brazil; Institute for the International Trade Negotiation: Brighton, UK, 2013.

20. Dale, V.H.; Keith, L.; Wiens, K.J.; Fargione, J. Biofuels: Implications for Land Use and Biodiversity; Ecological Society of America: Washington, DC, USA, 2010.

21. Groom, M.J.; Gray, E.M.; Townsend, P.A. Biofuels and biodiversity: Principles for creating better policies for biofuel production. Conserv. Biol. 2008, 22, 602-609. [CrossRef] [PubMed]

22. Fargione, J.; Hill, J.; Tilman, D.; Polasky, S.; Hawthorne, P. Land clearing and the biofuel carbon debt. Science 2008, 319, 1235-1238. [CrossRef] [PubMed]

23. Gheler-Costa, C.; Sabino-Santos, J.G.; Amorim, L.S.; Rosalino, L.M.; Figueiredo, L.T.M.; Verdade, L.M. The effect of preharvest fire on the small mammal assemblage in sugarcane fields. Agric. Ecosyst. Environ. 2013, 171, 85-89. [CrossRef]

24. Gerbens-Leenes, W.; Hoekstra, A.Y.; van der Meer, T.H. The water footprint of bioenergy. Proc. Natl. Acad. Sci. USA 2009, 106, 10219-10223. [CrossRef] [PubMed]

25. Scholten, W. The Water Footprint of Sugar and Sugar-Based Ethanol. Master's Thesis, University of Twente, Enschede, The Netherlands, April 2009.

26. Berndes, G. Bioenergy and water-the implications of large-scale bioenergy production for water use and supply. Glob. Environ. Chang. 2002, 12, 253-271. [CrossRef]

27. Berger, M.; Finkbeiner, M. Water footprinting: How to address water use in life cycle assessment? Sustainability 2010, 2, 919-944. [CrossRef]

28. Keam, S.; McCormick, N.; Howard, G.; Athanas, A. Guidelines on Biofuels and Invasive Species: IUCN 14; IUCN: Nairobi, Kenya, 2009.

29. Robertson, G.P.; Hamilton, S.K.; Del Grosso, S.J.; Parton, W.J. The biogeochemistry of bioenergy landscapes: Carbon, nitrogen, and water considerations. Ecol. Appl. 2011, 21, 1055-1067. [CrossRef] [PubMed]

30. Afework, D.; Tessema, T.; Yirefu, F. Efficacy of Integrated Water Hyacinth Management Strategies at Wonji-Shoa Sugar Factory. Ethiop. J. Weed Manag. 2008, 2, 57-70.

31. Kloos, H. Development, drought, and famine in the Awash Valley of Ethiopia. Afr. Stud. Rev. 1982, 25, 21-48. [CrossRef]

32. Barbour, M.G.; Burk, J.H.; Pitts, W.D. Terrestrial Plant Ecology, 3rd ed.; Cummings Publishing Co.: Menlo Park, CA, USA, 1987.

33. Takele, S.; Bekele, A.; Belay, G.; Balakrishnan, M. A comparison of rodent and insectivore communities between sugarcane plantation and natural habitat in Ethiopia. Trop. Ecol. 2011, 52, 61-68.

34. Butler, S.J.; Vickery, J.A.; Norris, K. Farmland biodiversity and the footprint of agriculture. Science 2007, 315, 381-384. [CrossRef] [PubMed]

35. Butler, S.J.; Brooks, D.; Feber, R.E.; Storkey, J.; Vickery, J.A.; Norris, K. A cross-taxonomic index for quantifying the health of farmland biodiversity. J. Appl. Ecol. 2009, 46, 1154-1162. [CrossRef]

36. Curtis, J.T.; McIntosh, R.P. The interrelations of certain analytic and synthetic phytosociological characters. Ecology 1950, 31, 434-455. [CrossRef]

37. Mekonnen, M.; Gebrehiwot, K.; Birhane, E.; Tewoldeberhan, S. Regeneration, Density and Diversity of Woody Vegetation in Awash National Park, Ethiopia. J. Drylands 2009, 2, 101-109. 
38. Aynekulu, E.; Aerts, R.; Denich, M.; Negussie, A.; Friis, I.; Demissew, S.; Boehmer, H.J. Plant diversity and regeneration in a disturbed isolated dry Afromontane forest in northern Ethiopia. Folia Geobot. 2016, 51, 115-127. [CrossRef]

39. Senbeta, F.; Teketay, D. Regeneration of indigenous woody species under the canopies of tree plantations in Central Ethiopia. Trop. Ecol. 2001, 42, 175-185.

40. Tilman, D.; Lehman, C. Human-caused environmental change: Impacts on plant diversity and evolution. Proc. Natl. Acad. Sci. USA 2001, 98, 5433-5440. [CrossRef] [PubMed]

41. Whittaker, R.H. Evolution and measurement of species diversity. Taxon 1972, 21, 213-251. [CrossRef]

42. Strong, D.R., Jr.; Simberloff, D.; Abele, L.G.; Thistle, A.B. Ecological Communities: Conceptual Issues and the Evidence; Princeton University Press: Princeton, NJ, USA, 2014.

43. Mugwedi, L.F.; Rouget, M.; Egoh, B.; Ramdhani, S.; Slotow, R.; Rentería, J.L. An Assessment of a Community-Based, Forest Restoration Programme in Durban (eThekwini), South Africa. Forests 2017, 8, 255. [CrossRef]

44. Shibru, S.; Balcha, G. Composition, Structure and regeneration status of woody species in Dindin Natural Forest, Southeast Ethiopia: An implication for conservation. Ethiop. J. Biol. Sci. 2004, 1, 15-35.

45. Endale, Y.; Derero, A.; Argaw, M.; Muthuri, C. Farmland tree species diversity and spatial distribution pattern in semi-arid East Shewa, Ethiopia. For. Trees Livelihoods 2017, 26, 199-214. [CrossRef]

46. Senbeta, F.; Denich, M. Effects of wild coffee management on species diversity in the Afromontane rainforests of Ethiopia. For. Ecol. Manag. 2006, 232, 68-74. [CrossRef]

47. Yineger, H.; Kelbessa, E.; Bekele, T.; Lulekal, E. Floristic composition and structure of the dry afromontane forest at Bale Mountains National Park, Ethiopia. SINET Ethiop. J. Sci. 2008, 31, 103-120. [CrossRef]

48. Takele, S.; Bekele, A.; Belay, G.; Balakrishnan, M. Pest status of rodents in Wonji sugarcane plantation. Ethiop. Int. J. Ecol. Environ. Sci. 2008, 34, 157-163.

49. Takele, S. Abundance, Composition and Habitat Association of Rodents in Wonji Shoa Area, Ethiopia. Master's Thesis, Addis Ababa University, Addis Ababa, Ethiopia, June 2006.

50. Savario, C.F.; Hoy, J.W. Microbial communities in sugarcane field soils with and without a sugarcane cropping history. Plant Soil 2011, 341, 63-73. [CrossRef]

51. Wallis, P.D.; Haynes, R.J.; Hunter, C.H.; Morris, C.D. Effect of land use and management on soil bacterial biodiversity as measured by PCR-DGGE. Appl. Soil Ecol. 2010, 46, 147-150. [CrossRef]

52. Sajjad, A.; Ahmad, F.; Makhdoom, A.H.; Imran, A. Does trash burning harm arthropod biodiversity in sugarcane? Int. J. Agric. Biol. 2012, 14, 1021-1023.

53. Srikanth, J.; Easwaramoorthy, S.; Kurup, N.K.; Santhalakshmi, G. Spider abundance in sugarcane: Impact of cultural practices, irrigation and post-harvest trash burning. Biol. Agric. Hortic. 1997, 14, 343-356. [CrossRef]

54. Adeba, D.; Kansal, M.L.; Sen, S. Assessment of water scarcity and its impacts on sustainable development in Awash basin, Ethiopia. Sustain. Water Resour. Manag. 2015, 1, 71-87. [CrossRef]

55. Lyra-Jorge, M.C.; Ciocheti, G.; Pivello, V.R. Carnivore mammals in a fragmented landscape in northeast of São Paulo State, Brazil. Biodivers. Conserv. 2008, 17, 1573. [CrossRef]

(C) 2017 by the authors. Licensee MDPI, Basel, Switzerland. This article is an open access article distributed under the terms and conditions of the Creative Commons Attribution (CC BY) license (http://creativecommons.org/licenses/by/4.0/). 